\title{
Beyond the Talk-Back
}

Performing Autoethnography and the Functions of Critique

\section{Desireé D. Rowe}

\begin{abstract}
Reflecting on my own experiences with talk-backs and audience responses, this manuscript uses metaphor to map the functions of autoethnographic performance critique. Through an exploration of vulnerability within performance, I turn to three key areas: theoretical accessibility, performativity, and accountability in order to chart how to engage in critique of performance autoethnography.
\end{abstract}

Keywords: performance, autoethnography, critique

In a talk-back for a recent autoethnographic performance, an audience member spoke up. "After watching you perform, I feel like you will never be happy," he says out from the darkness. The lights are still bright in my eyes, and I'm not sure exactly where the male voice emerges from the large, (thankfully) filled auditorium. His voice is deep and calm. My body is hot, still sweaty from performing, and I take loud, audible gulps from my dented water bottle as a way to steal some time before I have to answer his (presumed) question. I pull my shirt away from my body, self-conscious about the weight that I've gained over the past few years from two miscarriages and the birth of my daughter. I lick my lips and notice that I need some lip gloss; my lips are dry. I must have worn it all off during the work of performing. My show is about failure, and I talk about those miscarriages and the ways in which I/we can use miscarriage as way to ride the gray waves of life into a depressive realist perspective (Rowe, 2015). He thinks I can never be happy.

I feel vulnerable in the talk-back, but I know that it's a crucial part of this performance. As the water slides down the back of my throat, I know that this is the point where I'm supposed to talk about theory and its application to life. How happiness is (in part) a social construct that is created to maintain compliance within a system that force feeds us a mantra of loving it, free hugs, and catcalls asking me to "smile honey, you'd be much prettier." 
Instead, I ask him to rephrase the question. He says, "I mean, you should be thankful for what you have. We all have choices, this is what you've chosen."

Through literary devices, staging, music, and embodied performance, there is a lot left in the spaces between. Those liminal spaces offer the audience room to interpret the text in their own ways and through their lived experiences, and in this moment, slippage occurs. Berry (2006) has marked this moment in ethnographic writing where "the ability to be good at writing... seems to rely on minimizing verbiage. [And] as a result, the extent to which we can complicate ideas is lessened" (p. 101). Berry rightfully questions the blanks that we leave when narrating lives. While I disagree with Berry's either/or claim that less verbiage results in less to "complicate," I take his critique seriously. As performance autoethnographers, because of time constrictions or audience attention spans, we do leave those narrative gaps for audiences to fill in. As I sit in the talk-back, I reflect on a precise moment in my script where I ask the audience to do just this: "I've lived a clichéd life. You can fill in the blanks." These gaps, as Berry argues, can "minimize fairness, coherence, and, in effect, greater awareness" (p. 101).

How do we know when we leave those narrative gaps and when to avoid them at all costs? Gingrich-Philbrook's landmark (2005) essay, at the intersections of performance and autoethnography, marks an important shift in our conversations about the ethical impulse of creating autoethnographic performance when he emphasizes our need to reflexively engage the implications of our work within the scholarly community, marking a "double bind when artists encounter equally valued and equally insufficient messages or demands from the discourse enabling and constraining their praxis" (p. 302). Gingrich-Philbrook asks us to "embrace and experiment with different literary movements, particularly those more tolerant of, and constituted by, different orientations towards transparency" (p. 312). Scripting autoethnographic narrative for the stage becomes difficult in light of these (potentially) conflicting demands. The level of details that the performer shares can turn an audience away or pull them closer. Through this essay I work to offer a framework of critique for autoethnographic performance. To do this, I use my experiences to reflect on tangible and substantive criteria for critique.

My eyes have adjusted to the dim light on the audience and I can now see the audience member a little better. A white dude, dark hair, youngish. He's leaning forward in his chair, and his eyes meet mine.

There is a dance to the responses you give as a performer during a talk-back. You don't want to be too abrasive and risk alienating your audience, but you do want to be 
forceful, to show the audience that you are engaging their questions and comments, but that you are in charge here. I have a hard time dealing with those comments that, as Snyder-Young (2011) puts it, take an "amateurish stab at applied psychology" (p. 945). But I satisfy him with a theory-laden answer that drips with citationality. He leans back into his chair. Sighs. Content.

As a scholar who uses autoethnography, performance ethnography, and rhetorical methods, I am accustomed to conversations about rigor and discipline. I have been on both sides of the fence as a performer and as a critic when I cohosted the interdisciplinary podcast The Critical Lede. When discussing the work of others, I notice that "critiquing autoethnographic performance somehow seems to violate the sanctity of the story, evaluating not only the story but also the teller, and evaluating the teller on the scholar's, rather than the teller's terms" (Snyder-Young, 2011, p. 946). What was missing from our conversation then, and is still missing, is a nuanced and focused method of providing critique of autoethnographic performance.

Because autoethnographic performance engages a level of vulnerability that moves against traditional academic disciplines, it feels awkward and, at times, almost sadistic, to level a substantive critique against a performer who has made room for such vulnerability. However, it must be understood that the performer is doing just that, performing, and because of that risk, should realize that there will be conversation about the efficacy and engagement of the performance style, scripting, and staging choices. Like many others, I've seen my fair share of autoethnographic performances that left me wanting. I have entered into a space with a performer and experienced something with them and the audience but was unable to articulate a substantive critique because of the personal and vulnerable nature of the work. Performance autoethnography "leaves audience members in a tenuous position of wanting to respond but not knowing how, or if it is 'appropriate' to do so" (Berry, 2006, p. 106). I've also been on the other side of those not so amazing performances. I once had my upper ear pierced (in two places) on stage by a not so well-trained piercer to mark pain as a metaphor. It wasn't a metaphor. It was (literally) bloody pain. The blood ran down my cheek, and I couldn't hold back my pitiful yelps of pain. It was awful. I was awful. I look back and wonder how I wanted the audience to respond.

"Provocative can be sexy, yet sometimes feels dirty."

(Berry, 2006, p. 101)

Performance is a liaison and agreement that you enter into without knowing much about the audience; you become vulnerable and they watch. Hopefully you both leave 
changed in some way, mulling over what just happened and looking for more. Much like feminist and queer porn that "seeks to create alternative images and develop its own aesthetics and iconography to expand established norms and discourses" (Taormino, Shimizu, Penley, \& Miller-Young, 2013, p. 10), performance autoethnography also seeks to make space for narratives that are counter to normative discourses.

In her discussion of the future of performance studies, Madison (2013) asks the provocative question, "What is distinctive about communication that is constituted by performance and performance that is constituted by communication?" (p. 208). I take this question in relation to the critique of performance autoethnography to help offer a path for understanding what value performance offers the audience, the performers, and the larger scholarly community. The three key tenets below are not mutually exclusive or exhaustive; they are suggestions for tangible ways that performance and ethnography scholars can offer substantive critique for scholars who perform autoethnography.

\section{Theoretically Accessible}

To mark performance autoethnography as different from literary performance (Gingrich-Philbrook, 2005), critical theory has to be both explicitly and implicitly marked in both the script and performance. As Madison (2013) encourages, the job of performance is "making the ordinary so rapidly unfamiliar, and for stretching critical theory toward new, necessary, and more embodied claims" (p. 208). This can take many forms, from interweaving theory into personal narrative, "showing" theory on stage through props or blocking, or offering carefully woven and well-placed oral citations of critical theory.

The relationship of performance autoethnography with critical theory must be two-fold. First, the performance must offer a compelling and grounded understanding of complex (or "high") theory through the intersections of lived experience. As a method that thrives on being intersectional and accessible, performance autoethnography needs to engage those beyond the academic in conversations about theory, offering another translation of the impacts of theory on the lived experiences of those in the audience.

Second, because performance is unique in its ability to show the embodied reality of theory, performance autoethnography must expand the theoretical construction, pushing it into another realm or dimension. Rather than just performing/demonstrating the lived implications of Critical Theory X, performance autoethnography, because it is uniquely situated to force a material understanding with the audience, 
needs to leave the audience with an understanding of Critical Theory XY, adding and layering other levels of signification and making theory inescapable in conversation with experience. Perhaps we don't give every nuanced detail of the experience, leaving the audience with some of those "provocative discursive moments" (Berry, 2006, p. 101) that do not tell the whole story through personal narrative. Rather, by creating a type of theoretical chimera, we have opened up new discursive moments for engagement and conversation and pushed aside the need for complete and total narrative transparency.

\section{Performative}

Performance autoethnography starts with embodiment as the active engagement of the body and mind, so flesh must be part of the discussion. Standing between theory and practice means that it is not purely either one, neither a skill-based vocation nor a secure cultural object. Performance autoethnography is an institutional chiasmus (Jackson, 2011) within a unique space that does not privilege linguistic over nonlinguistic modes of knowledge. Conquergood (2002) describes this as the "commingling of analytical and artistic ways of knowing that unsettles the organization of knowledge" (p. 151). The challenge of performance autoethnography is to be as aware as possible of your position in relation to the positions of others and then take steps to maintain or change those positions, because performance studies exists between action and theory. As Madison (2013) offers, "with labor, the performative gains strength through the sisterhood of performativity and performance" (p. 209). To do this, the performer must engage in artistic practice, fieldwork, theorizing, and activism while recognizing how her body (and those around her) are tangled in oppressive structures.

Because performance "calls into question the privilege of academic authority by including all members of a speech community as potential artists, all utterances as potentially aesthetic, all events as potentially theatrical, and all audiences as potentially active participants who can authorize artistic experience," a new level of academic subject must be considered (Pelias \& VanOosting, 1987, p. 221). The performance script, when paired with a body on stage, should mark a clear disruption of normative, hegemonic structures. Performance autoethnography investigates forms of epistemology: performativity, performance as/and representation, performance as social behavior, performance and/as experience. It can be intimidating, but also exhilarating, because of the freedom of the scholar to investigate a phenomenon in a way that does not restrain the subject. 


\section{Accountable}

While performers have a significant amount of freedom (and responsibility) to explore the epistemological foundations of understanding, they must also be accountable to the cultural location in which their performances are centered. Each performance must demonstrate an accountability that marks the subject position of the performer. While this can be difficult because "the aesthetic/epistemic double bind is no longer a double bind, but a fluid horizon that is expected and necessary," (Madison, 2011, p. 136), I turn to Deleuze and Guattari's articulation of lines of flight and apply them to the work of De la Garza (2004). The understanding of the critical performance autoethnographer as one who resists the concretization of borders and boundaries within ethnographic research is both freeing and, potentially, allows space for the performer to neglect their positionality. Specifically, within critical performance autoethnography, practice is centered on the visceral need to rearticulate the position of the body in relation to the site.

Deleuze and Guattari (1987) offer a rhizomatic perspective on a concept of mapping as "fostering connections between fields ... open and connectable in all of its dimensions; it is detachable, susceptible to constant modification, reworked by an individual, group or social formation, the maximum opening of bodies" (p. 12). Under this framework, performance autoethnography can learn lessons from rhizomatic mapping as it removes the dialectical nature of communication, reforming it as "a line of becoming that does not connect points but runs transversally among and between points" (Sotirin, 2003, p. 67) and allows the performer a range of freedom that is not normally admissible in traditional (historically anthropological) ethnography. In reformulating the dialectic to include multiple points, the autoethnographer articulates a position that does not reify binaries of engagement, such as us/them, self/other, mind/body, but works toward a Deleuzian concept of assemblages. I turn to De la Garza's fieldwork as an illustrative example of how the performer inherently reaches this moment. De la Garza (2004) notes that "a critique is not a critique of an agent external to myself. The structures and voices that have oppressed are part of me. My method of inquiry had to be able to maintain this dialectic" (p. 19). Here De la Garza offers a method of mapping the dialectic that allows for multiple perspectives and meaning making and, in effect, negating traditional notions of the dialect in favor of Deleuze and Guattari's rhizomatic mapping, which is inclusive of more nodes of intersection. In this way, performance autoethnography is already being allowed to be "drawn on a wall, conceived as a work of art, constructed as a political action or as meditation" 
because the freedom the ethnographer has to derive implications (Deleuze \& Guattari, 1987, p. 12).

"Performance performs like a promiscuous lover."

(Madison, 1999, p. 108)

After each performance I like to smoke a cigarette. Go outside, be alone, and reflect on what the hell just happened. After my talk-back interaction with the man in the dark, I stepped outside. It was a cold Minnesota-winter evening, but it helped take the edge off. I could feel the sweat on the back of neck freeze. I was standing in the dark, at the back of the building, and could see the audience quickly running into their cars, bracing from the freezing wind.

This is the part where I would say that he met me on the side of the building and showed the appreciation for my performance that I was looking for in his comments earlier. Standing there, freezing, I scanned the parking lot for him, but I couldn't really remember his face. He looks like everyone else now, far away and full of longing.

\section{References}

Berry, K. (2006). Implicated audience member seeks understanding: Reexamining the "gift" of autoethnography. International Journal of Qualitative Methods, 5(3), 94-108. doi:10. $1177 / 160940690600500309$

Conquergood, D. (2002). Performance studies: Interventions and radical research. Drama Review, 46, 145-156. doi:10.1162/105420402320980550

De la Garza, S. A. (2004). María speaks: Journeys into the mysteries of the mother in my life as a Chicana. New York, NY: Peter Lang.

Deleuze, G., \& Guattari, F. (1987). A thousand plateaus: Capitalism and schizophrenia (B. Massumi, Trans.). Minneapolis: University of Minnesota Press.

Gingrich-Philbrook, C. (2005). Autoethnography's family values: Easy access to compulsory experiences. Text and Performance Quarterly, 25, 297-314. doi:10.1080/1046293050 0362445

Jackson, S. (2011). Social works: Performing art, supporting publics. New York, NY: Routledge. Madison, D. S. (1999). Performing theory/embodied writing. Text and Performance Quarterly, 19, 107-124. doi:10.1080/10462939909366254

Madison, D. S. (2011). The labor of reflexivity. Cultural Studies $\leftrightarrow$ Critical Methodologies, 11, 129-138. doi:10.1177/1532708611401331

Madison, D. S. (2013). That was then and this is now. Text and Performance Quarterly, 33, 207-211. doi:10.1080/10462937.2013.790557

Pelias, R. J., \& VanOosting, J. (2009). A paradigm for performance studies. Quarterly Journal of Speech, 73, 219-231. doi:10.1080/00335638709383804 
Rowe, D. D. (2015). Cruel optimism and the problem of positivity: Miscarriage as a model for living. In R. E. Silverman \& J. Baglia (Eds.), Communicating pregnancy loss: Narrative as a method for change (pp. 259-266). New York, NY: Peter Lang.

Snyder-Young, D. (2011). "Here to tell her story": Analyzing the autoethnographic performance of others. Qualitative Inquiry, 17, 943-951. doi:10.1177/1077800411425149

Sotirin, P. (2003). Suckling up to the BwO. In J. D. Slack (Ed.), Animations [of Deleuze and Guattari] (pp. 59-74). New York, NY: Peter Lang.

Taormino, T., Shimizu, C. P., Penley, C., \& Miller-Young, M. (Eds.). (2013). The feminist porn book: The politics of producing pleasure. New York, NY: The Feminist Press.

\section{About the Author}

Desireé D. Rowe (Ph.D, Arizona State University, 2009) is an assistant professor of communication studies at Towson University. 